\title{
College Students' Entrepreneurship Education under the Guidance of Socialist Core Values
}

\author{
Li Fang ${ }^{1}$,Wei-yu Zhang ${ }^{1,}$, Kai-li Ren ${ }^{2}$ \\ ${ }^{1}$ Beihua University ,Jilin, China \\ ${ }^{2}$ Beihua University, College of physical education, Longteng innovation and entrepreneurship education base \\ *Corresponding author
}

Keywords: Socialist core values, Entrepreneurship education.

\begin{abstract}
. the core values of socialism play an ideological guiding role, theoretical guidance function and thinking stimulating effect on entrepreneurship education and education in Colleges and universities. There are many problems in the process of College Students' Entrepreneurship education. Related knowledge, entrepreneurship education of college students to strengthen and improve the management system, optimize the campus environment and pay attention to the development of entrepreneurship education entrepreneurial practice is the effective way to carry out students' Entrepreneurship Education under the guidance of socialist core values.
\end{abstract}

\section{Introduction}

November 2012, the eighteen largest of the Communist Party of China defined the content of socialist core values for the first time. The socialist core values are of far-reaching significance to the overall development of mankind and social progress, to a well-off society and to the great rejuvenation of the Chinese nation. With the rapid development of higher education in China, the scale of enrollment increases gradually, and the employment pressure of students increases year by year. How to solve the employment problem of college students has become an important part of the work of students' Education in universities. It is one of the important and effective ways to alleviate the employment pressure of college students to carry out entrepreneurship education under the guidance of the socialist core values.

\section{The significance of the socialist core values in the process of College Students' Entrepreneurship Education}

2.1 Ideological guidance. The socialist core values is facing the new situation of the global cultural exchange and confrontation and the combination of China's current social ideology diversification characteristics put forward, is to adapt to the development needs of the times more than summary. Its spirit core has strong appeal and cohesive force. In guiding the students in the entrepreneurial process to analyze the current employment situation and market demand, according to the international and domestic changes to guide and cultivate students the effectiveness of mainstream values, so that students can effectively adapt to changes in the development of the society. Guide students to meet the requirements of the times and start their own businesses ideologically.

2.2 It has theoretical guidance function. The socialist core values have certain theoretical guiding function for college students' Entrepreneurship education. Marx's multidimensional view of human values is an important theoretical basis of socialist core values. On the line in the process of entrepreneurship education for college students, adhere to the Mark doctrine as an important guiding ideology of the theory, a firm belief in the cultivation of students' ideal, to establish a 
correct world outlook, outlook on life and values of the concept of entrepreneurship has important theoretical guidance for college students to enhance the function of.

2.3 It has the effect of thinking priming. The socialist core value is proposed according to the situation of our country, firmly grasp the spiritual pillar effect, by linking theory with practice, identify the interests and ideas resonate, to stimulate thinking effect by thinking of entrepreneurship and innovation concept. The college students with the socialist core value of entrepreneurship education foundation, can effectively bound the university student's ideological liberation, so that the students can go its own way of entrepreneurship, stimulate the students' creative thinking, to enhance the attractiveness of entrepreneurship. Enhance the quality and effect of entrepreneurship education in Colleges and universities.

\section{The main problems existing in the process of College Students' Entrepreneurship Education}

3.1 Entrepreneurship education theory research level is general. Entrepreneurship education faces the pressure of graduates' employment after the enrollment expansion, which is an effective way to expand graduates' employment effectively. As the country pays more attention to the way out of college graduates, all colleges and universities have gradually started entrepreneurship education to promote employment. However, in the process of entrepreneurship education, the weakness of the system theory is an important problem in the process of entrepreneurship education in Colleges and universities. In the process of entrepreneurship practice, it has not been able to effectively solve the problems encountered, and often lead to theoretical research can not be more fully, and play a positive role in the practice process.

3.2 Capital investment and practical activities are facing difficulties. Nowadays, college students lack the process of entrepreneurship education funding, they only have to form a team, some small and medium-sized enterprises or companies, through the introduction of their entrepreneurial projects, to get sponsorship related enterprises and companies. In addition, they are usually college students, or just graduated, and there is no guarantee for their own funds, the general family in order to provide college students have spent their savings, so the problem of capital investment. Lack of funds, the implementation of practice is restricted, practical activities can not be carried out, the entrepreneurial process will encounter difficulties, at the same time will greatly dampen their enthusiasm for the future of entrepreneurship, entrepreneurial activities will lose confidence. The future needs some positive measures to solve the difficulties in reality, thus laying a solid material foundation for future successful entrepreneurship.

3.3 The level of entrepreneurial teachers is relatively weak. Whether entrepreneurship education can achieve the desired results has a strong correlation with the guidance of entrepreneurial teachers. In the process of entrepreneurship education in Colleges and universities, entrepreneurship education theory in students' entrepreneurship education guidance teachers tend to have a certain level, but in the entrepreneurial practice experience less or no entrepreneurial experience, which will seriously affect the students' Entrepreneurship . In the process of student entrepreneurship, schools can not provide students with targeted practical guidance, thus reducing students' interest in entrepreneurship. Therefore, the relatively weak level of entrepreneurial faculty is one of the major problems in the process of College Students' Entrepreneurship education.

\section{The socialist core values of students under the guidance of entrepreneurship education, an effective way}

4.1 Strengthen the relevant knowledge of College Students' Entrepreneurship education. On the one hand, to promote the implementation of entrepreneurship education for college students, the first is to make students aware of entrepreneurship education is not only to teach students the ability to start a business, not just in order to solve the difficult problem of employment of contemporary college students, entrepreneurship education mainly look at the consciousness of University

students' Entrepreneurship and entrepreneurship training, psychological quality and 
entrepreneurship the ability and knowledge of the comprehensive exercise. On the other hand, in the training objectives of education in our country, there are few mining activities can the depth of students' initiative and creativity, students' entrepreneurial awareness is relatively weak, so the cultivation of ripe students pioneering consciousness has become an important factor in the implementation of entrepreneurship education in Colleges and universities, entrepreneurship awareness is a positive and optimistic consciousness in essence, lay a good ideological foundation for the students' entrepreneurial success, and become the most important factors to promote college students' entrepreneurship. At the same time, in the face of the current severe pressure of competition, college students also need to have the psychological quality and a certain amount of knowledge and ability to reserve. Having comprehensive practical ability and able to solve all kinds of problems in the process of entrepreneurship will be the necessary condition and important guarantee for the success of College students.

4.2 Improve the management system and optimize the campus environment for entrepreneurship education. First of all, in order to promote the smooth development of entrepreneurship education for college students, strengthen teaching management and student management can not be ignored, to create an environment conducive to the full development of students' personality, freedom of the business environment and atmosphere, and constantly improve the school entrepreneurship education in aspects of management mechanism and establish a scientific evaluation index. Secondly, the relevant departments of the school do a good job of propaganda education, is conducive to creating a strong entrepreneurial culture atmosphere, thereby further promoting the development of entrepreneurial education. On the one hand, through newspapers, periodicals in University, blackboard and painting and other forms of publicity for entrepreneurship education, on the other hand, through the establishment of the WeChat platform, and the students to entrepreneurship education interaction and discussion, continue to inspire teachers and students entrepreneurial spirit.

4.3 Pay attention to the practice of entrepreneurial activities. On the one hand, effective combination of classroom teaching and extracurricular practice. In the development of entrepreneurship education, realize the effective combination of theory and practice is the perfect combination of classroom teaching of teachers and students of extra-curricular activities, which requires teachers to constantly strengthen the practice teaching design, encourage students to participate in the skills competition, guiding students' social practice, improve their professional ability. On the other hand, lead students to visit related enterprises. Universities can lead students to social practice as a link, organize the students to carry out the investigation and visit the enterprise's internal structure and operating conditions of enterprises, so that they feel a deep enterprise culture, the hard to let them in the real social life to understand the unique business, struggle and joy.

\section{References}

[1]Zhang Xia. The necessity and implementation of entrepreneurship education in Colleges and universities [D]. Shaanxi Normal University, 2006.

[2]Shang Hengzhi. College students' entrepreneurship education way of [J]. theory and practice of education in Colleges and universities, 2009

[3]Yu Ruifen. On the practice of socialist core value system in Entrepreneurship Education [J]. modern business industry, 2014

[4] Yu Yuhua. Practical exploration of socialist core value system [J]. ideological and theoretical education. 2014 (01)

[5] Li Congdong Entrepreneurship education and guidance strategy of [J]. Journal of Jiangxi Vocational and Technical College of Electricity 2017 (02)

[6] Chang Hong. Current situation and Countermeasures of entrepreneurship education for college students [J]. Journal of Heilongjiang Institute of education. 2017 
[7]Yang Bo. Research on the management model of college students entrepreneurship education [J]. human resources development. 2017 (12)

[8] Wei Xi.Exploration and Reflection on the innovation path of College Students' Entrepreneurship Education [J].. Contemporary educational practice and teaching research. 2017 (02) 